\title{
Anion Solvation Regulation Enables Long Cycle Stability of Graphite Cathodes
}

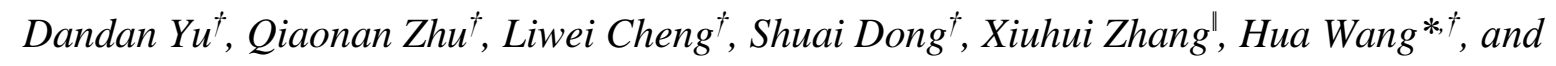
Nianjun Yang $*, t$

\section{AUTHOR ADDRESS}

†School of Chemistry, Beijing Advanced Innovation Center for Biomedical Engineering, Key Laboratory of Bio-Inspired Smart Interfacial Science and Technology, Ministry of Education, Beihang University, Beijing 100191, China

${ }^{\ddagger}$ Institute of Materials Engineering, University of Siegen, Siegen, 57076 Germany

"School of Chemistry and Chemical Engineering, Beijing Institute of Technology, Beijing 100081, China

\section{Experimental section}

Preparation of electrolytes

Firstly, sodium hexafluorophosphate $\left(\mathrm{NaPF}_{6}, \mathrm{Alfa}\right)$ was dissolved in the mixture of ethylene carbonate (EC, Alfa), dimethyl carbonate (DMC, Acros) and ethyl methyl carbonate (EMC, Aladdin) at the volume ratio of 1:1:1 to prepare $1 \mathrm{M} \mathrm{NaPF}_{6} / \mathrm{EC}-\mathrm{DMC}-\mathrm{EMC}$ as the blank electrolyte. Then, fluoroethylene carbonate (FEC, Alfa) was added into this electrolyte to 
obtain new sodium-ion $\left(\mathrm{Na}^{+}\right)$-based electrolytes with different FEC concentrations, in which the weight of FEC accounts for $2 \mathrm{wt} \%, 5 \mathrm{wt} \%, 10 \mathrm{wt} \%$ and $20 \mathrm{wt} \%$, respectively, of the blank electrolyte. Furthermore, the lithium-ion $\left(\mathrm{Li}^{+}\right)$-based electrolyte with $10 \mathrm{wt} \% \mathrm{FEC}$ was also prepared by utilizing lithium hexafluorophosphate $\left(\mathrm{LiPF}_{6}\right)$ to replace $\mathrm{NaPF}_{6}$. All electrolytes were prepared in the Ar-filled glove box with $\mathrm{O}_{2}<0.01$ ppm and $\mathrm{H}_{2} \mathrm{O}<0.01 \mathrm{ppm}$.

\section{Fabrications of electrodes}

Graphite cathodes were prepared by blending natural graphite powder (325 mesh, XFNANO) with carbon black and carboxymethyl cellulose (CMC, Acros) at the weight ratio of $80: 10: 10$ by using water as the solvent to obtain the homogeneous slurry, and then coated onto aluminum (Al) foils and dried at $60{ }^{\circ} \mathrm{C}$ for $24 \mathrm{~h}$. Tin $(\mathrm{Sn})$ foils (Sinopharm Chemical Reagent Co. Ltd, $0.1 \mathrm{~mm}, 99.9 \%$ ) were utilized as both anode materials and current collectors of $\mathrm{Sn}(-) / /$ graphite $(+)$ batteries by cutting into circular sheets with the diameter of $14 \mathrm{~mm} . \mathrm{N}-$ doped carbon nanofibers (NCF) were also employed as anodes to match with graphite cathodes. Chitin (Sigma, C9213) was firstly preheated from room temperature to $300{ }^{\circ} \mathrm{C}$ for $1.5 \mathrm{~h}$ at a heating rate of $1{ }^{\circ} \mathrm{C} / \mathrm{min}$ to stabilize the nanostructure and then carbonized at $700{ }^{\circ} \mathrm{C}$ for $2 \mathrm{~h}$ in a tube furnace under argon (Ar) flow at $5{ }^{\circ} \mathrm{C} / \mathrm{min}$ to fabricate NCF. The NCF electrodes were prepared by coating the mixture of $80 \mathrm{wt} \%$ active materials, $10 \mathrm{wt} \%$ carbon black, and $10 \mathrm{wt} \%$ CMC on copper foils.

\section{Characterization}

The sample morphology and microstructure were observed by using field-emission scanning electron microscope (FEI Quanta 250 FEG) and transmission electron microscope (Tecnai G2 F20 S-TWIN). The solvation structure of different electrolytes was characterized by using NMR (AVANCE III HD 600MHz), Raman (inVia-Reflex Raman spectrometer), FTIR (Nicolet IS50 spectrophotometer, ATR mode) spectra. The ${ }^{19} \mathrm{~F}$ NMR spectrum of graphite cathodes was obtained by solid-state NMR spectrometer (Bruker AVANCE NEO 500MHz).

The X-ray diffraction (XRD) patterns were taken on a Rigaku Dmax 2200 X-ray diffractometer under $\mathrm{Cu} \mathrm{K \alpha}$ radiation $\left(\lambda=1.5416 \AA\right.$ ). To study the $\mathrm{PF}_{6}^{-}$(de-)intercalation mechanism of graphite cathodes, $\mathrm{Na}(-) / /$ graphite $(+)$ batteries at different potentials were disassembled and then the recycled electrodes were sealed by protective films in the Ar-filled glove box before XRD measurement at a scanning speed of $2 \% \mathrm{~min}$. The X-ray photoelectron 2 
spectra (XPS) were collected by using Thermo escalab 250Xi X using Al K $\alpha$ radiation. The electrodes after cycling were firstly disassembled in an Ar-filled glove box, then rinsed with $\mathrm{DMC}$, and subsequently sealed in an air-tight tube after drying to avoid directly contact with air before transporting for XPS characterization. The collected spectra were referenced to the C 1s binding energy of $284.8 \mathrm{eV}$ and analyzed using X-peak software.

\section{Electrochemical measurements}

Electrochemical cycling tests were carried out using CR2032-type coin cells with glass fiber separators on CT 2001A Land battery testing systems (Jinnuo Electronics Co. Ltd., China) at room temperature. Firstly, $\mathrm{Na}(-) / /$ graphite $(+)$ batteries composed of $\mathrm{Na}$ metal anodes and graphite cathodes were assembled by utilizing $\mathrm{Na}^{+}$-based electrolytes with different FEC concentrations to disclose the effects of FEC co-solvent on the anion intercalation and extraction chemistry of graphite cathodes. Moreover, to further demonstrate the role of FEC in the cell performance, $\mathrm{Na} / \mathrm{Na}$ symmetric cells were assembled in the Ar-filled glove box using different electrolytes. Electrochemical impedance spectra (EIS) were obtained in the frequency range of $100 \mathrm{kHz}-0.1 \mathrm{~Hz}$ with an amplitude of $10 \mathrm{mV}$ (1400 celltest system, Solartron). The high-voltage stability of electrolytes was studied by linear scan voltammetry (LSV) of Na/Al coin cells at $0.5 \mathrm{mV} / \mathrm{s}$ from 2.0 to $5.0 \mathrm{~V}$. In addition, the performance of $\mathrm{Li}(-) / /$ graphite $(+)$ batteries and $\mathrm{Li} / / \mathrm{Li}$ symmetric cells were also tested to illustrate the universality of FEC cosolvent in electrolytes.

Furthermore, $\operatorname{Sn}(-) / /$ graphite $(+)$ full cells and $\mathrm{NCF}(-) / /$ graphite $(+)$ batteries were assembled to evaluate the applicability of FEC-modified electrolytes. Sn foils were firstly discharged at $20 \mu \mathrm{A} / \mathrm{cm}^{2}$ for $72 \mathrm{~h}$ in half cells using $\mathrm{Na}$ metal as both the counter and reference electrodes, and then recycled from coin cells for assembling Sn(-)//graphite(+) batteries. Before long-term cycling, $\operatorname{Sn}(-) / /$ graphite(+) batteries were pre-cycled at the low current density of $100 \mathrm{~mA} / \mathrm{g}$ for 50 cycles. Similarly, NCF electrodes were firstly cycled at $20 \mathrm{~mA} / \mathrm{g}$ in half cells for 3 cycles in the voltage range of $0.01-3 \mathrm{~V}$ and discharged to $0.01 \mathrm{~V}\left(v s . \mathrm{Na} / \mathrm{Na}^{+}\right.$), then disassembled form coin cells, and subsequently matched with graphite cathodes to construct $\mathrm{NCF}(-) / /$ graphite $(+)$ batteries where the mass ratio of cathode to anode is $2: 1$. The areal mass loading of graphite in graphite cathodes is determined to be $1.0 \sim 1.5 \mathrm{mg} / \mathrm{cm}^{2}$, the amount of electrolyte is controlled to be $50 \mu \mathrm{L}$ for one single cell, and the applied voltage window is 2.0 - 
4.8 $\mathrm{V}$ for testing the cell performance unless explicitly stated. The specific capacities and current densities of graphite cathode-based batteries are all calculated based on the mass of the graphite active material in cathode.

\section{Calculation methods}

All the first-principles calculations were performed in the Gaussian 09 program package ${ }^{1}$ using the Lee-Yang-Parr correlation functional (B3LYP) combined with 6-31+G(d) level of theory. The solvent effects were considered using an implicit solvation model based on density (SMD) (acetone). Based on the optimized molecular structures, the pictorial representations of the molecules and HOMO/LUMO plots were prepared using the Multiwfn 3.6 software package $^{2}$ and VMD visualization program. ${ }^{3}$ Molecular dynamics (MD) simulations were carried out by using the GROMACS 5.3 package $^{4-11}$ with OPLS-AA ${ }^{12}$ force field for $1 \mathrm{M}$ $\mathrm{NaPF}_{6}$ with solvent molecules (EC, EMC, DMC and FEC). The $1 \mathrm{M} \mathrm{NaPF}_{6}$ in EC-DMC-EMC $\left(1: 1: 1\right.$, vol) electrolyte cell was composed of $30 \mathrm{Na}^{+}, 30 \mathrm{PF}_{6}^{-}, 441 \mathrm{EC}, 291 \mathrm{EMC}$, and $354 \mathrm{DMC}$ species, while the $10 \mathrm{wt} \%$ FEC-modified electrolyte cell also includes 99 FEC species. The molecules were firstly filled randomly and arranged periodically in the XYZ direction into a $53 \times 53 \times 53 \AA^{3}$ cubic boxes with PACKMOL software. ${ }^{13}$ The systems were equilibrated for 100 ps followed by a 100 ps simulation in isothermal-isobaric ensemble (NPT), using V-rescale thermostat and Berendsen barostat to maintain the temperature at $298 \mathrm{~K}$ and pressure at 1 bar, respectively. The equation of motion was integrated by the leapfrog algorithm with a time step of 2 fs. The partial atomic charges of all molecules were obtained by optimizing the geometry with B3LYP/6-311+G(d, p) basis set using the Gaussian 09 package and then fitting the electrostatic potential surface by the RESP method. The bonded and non-bonded parameters were extracted from OPLS-AA force field. The Particle-Mesh-Ewald (PME) method was employed for the long-range electrostatic interactions with the Fourier spacing of $0.16 \mathrm{~nm}$. The cutoff distance was set to $1.0 \mathrm{~nm}$ for the electrostatic and Lennard-Jones interactions. The snapshot was drawn with VMD program.

The binding energy $\left(E_{\text {binding }}\right.$ ) between $\mathrm{Na}^{+}$cations $/ \mathrm{PF}_{6}^{-}$anions and solvent molecules was calculated with the equation below:

$$
E_{\text {binding }}=E_{\text {ion-solvent }}-E_{\text {solvent }}-E_{\text {ion }}
$$

where $E_{\text {ion-solvent }}$ represents the total energy of the monomer solvent molecule interacting 4 
with a single $\mathrm{Na}^{+}$or $\mathrm{PF}_{6}^{-}, E_{\text {solvent }}$ is the energy of the isolated monomer solvent molecule, and $E_{\text {ion }}$ is the energy of a single $\mathrm{Na}^{+}$or $\mathrm{PF}_{6}^{-}$.
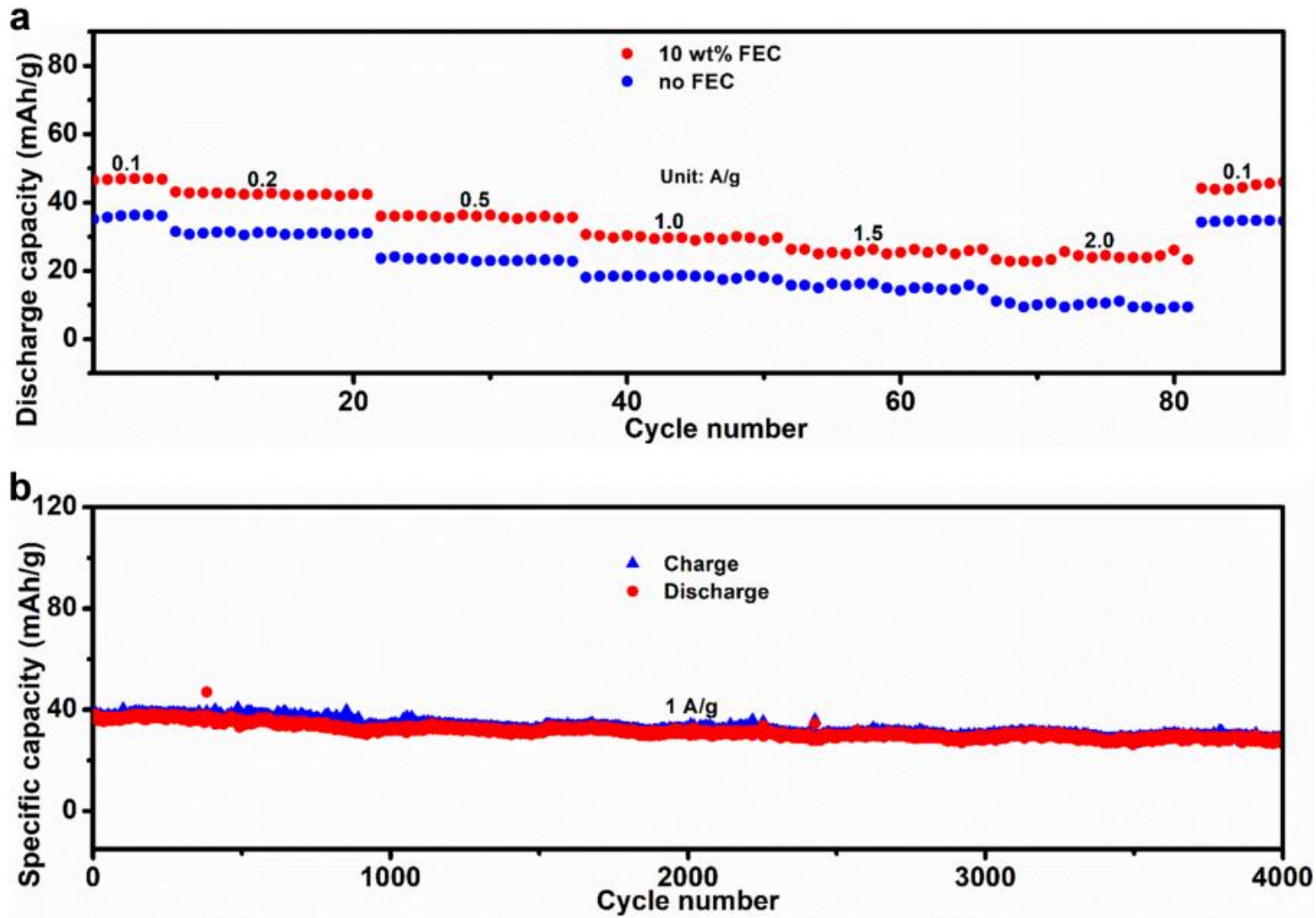

Figure S1. (a) Rate performance of graphite cathodes at different current densities when utilizing two electrolytes with and without $10 \mathrm{wt} \% \mathrm{FEC}$, respectively. (b) Cycling performance of graphite cathode at $1 \mathrm{~A} / \mathrm{g}$ when utilizing the $10 \mathrm{wt} \%$ FEC-modified electrolyte. 

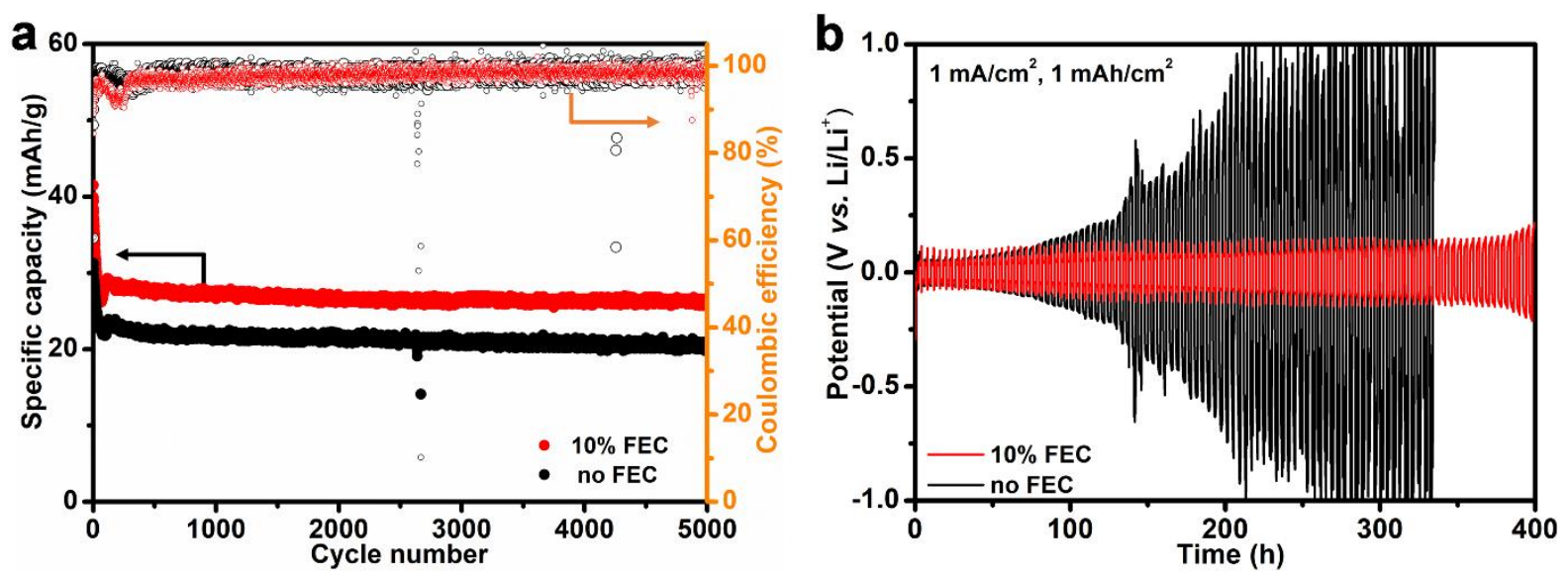

Figure S2. (a) Cycling performance of $\mathrm{Li}(-) / /$ graphite $(+)$ batteries at $500 \mathrm{~mA} / \mathrm{g}$ in the potential window of 2.0-5.0 $\mathrm{V}$ and (b) potential profiles of Li plating/stripping in $\mathrm{Li} / / \mathrm{Li}$ symmetric cells at $1.0 \mathrm{~mA} / \mathrm{cm}^{2}$ for $1 \mathrm{mAh} / \mathrm{cm}^{2}$ when utilizing two $\mathrm{Li}^{+}$-based electrolytes with $10 \mathrm{wt} \% \mathrm{FEC}$ and without FEC, respectively.

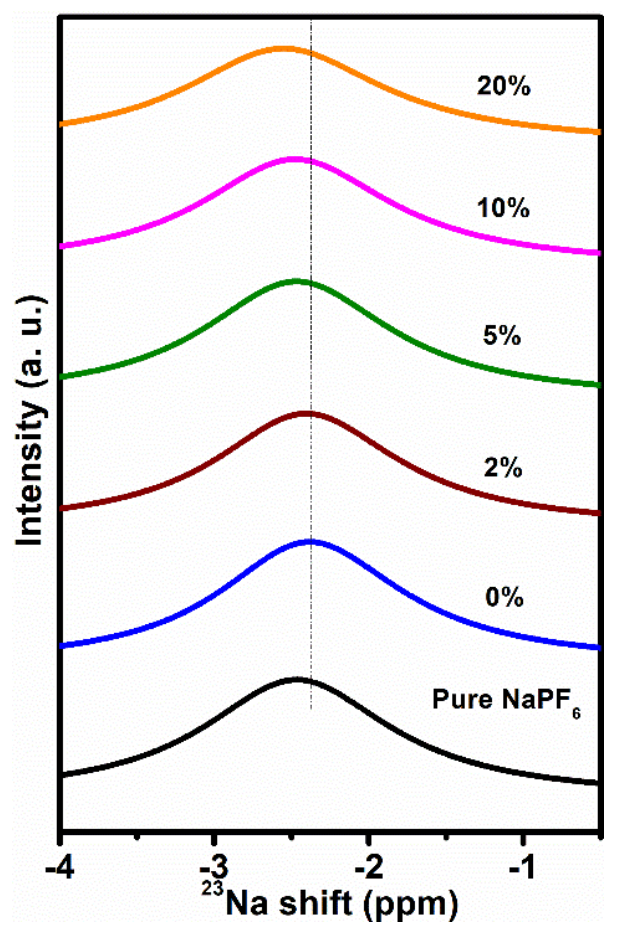

Figure S3. Chemical shifts of ${ }^{23} \mathrm{Na}$ NMR spectra of electrolytes with different FEC contents as compared to pure $\mathrm{NaPF}_{6}$. 

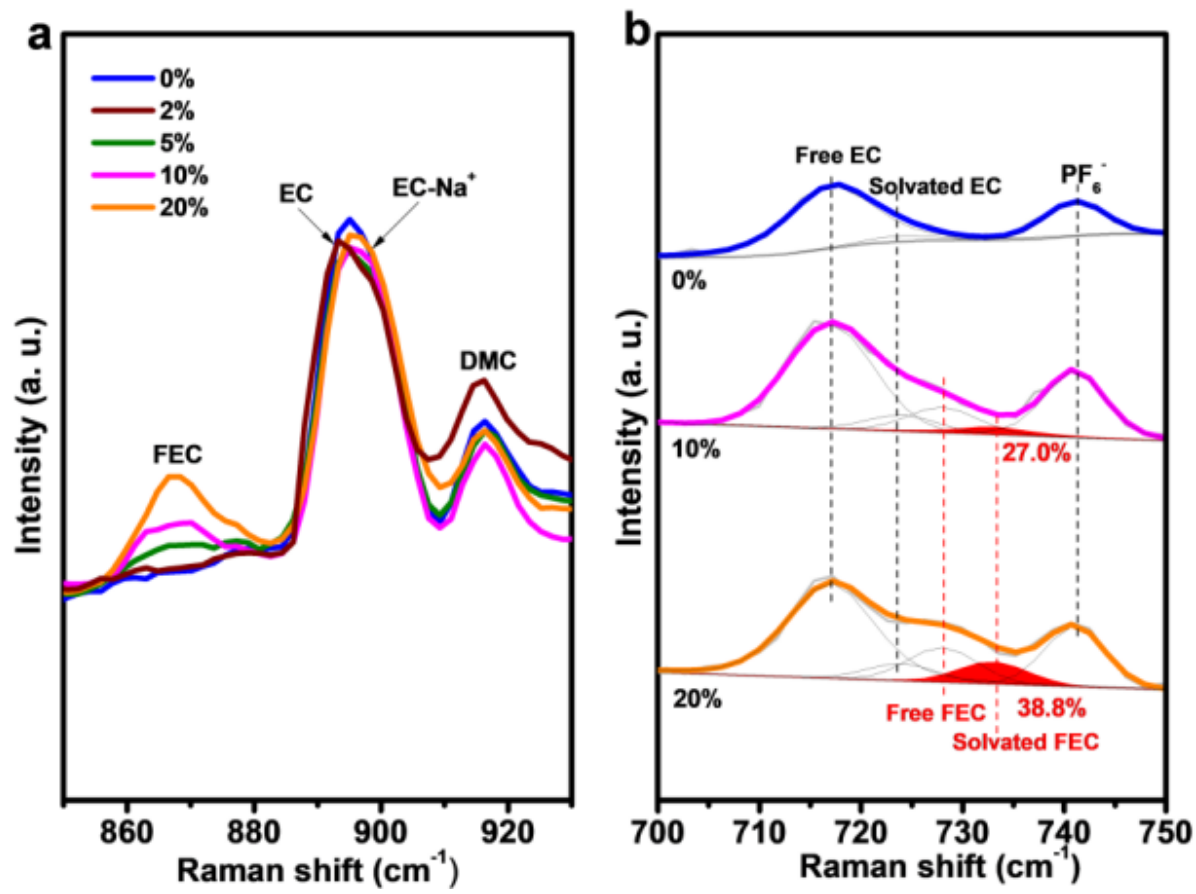

Figure S4. (a, b) Raman spectra of electrolytes with different FEC contents.
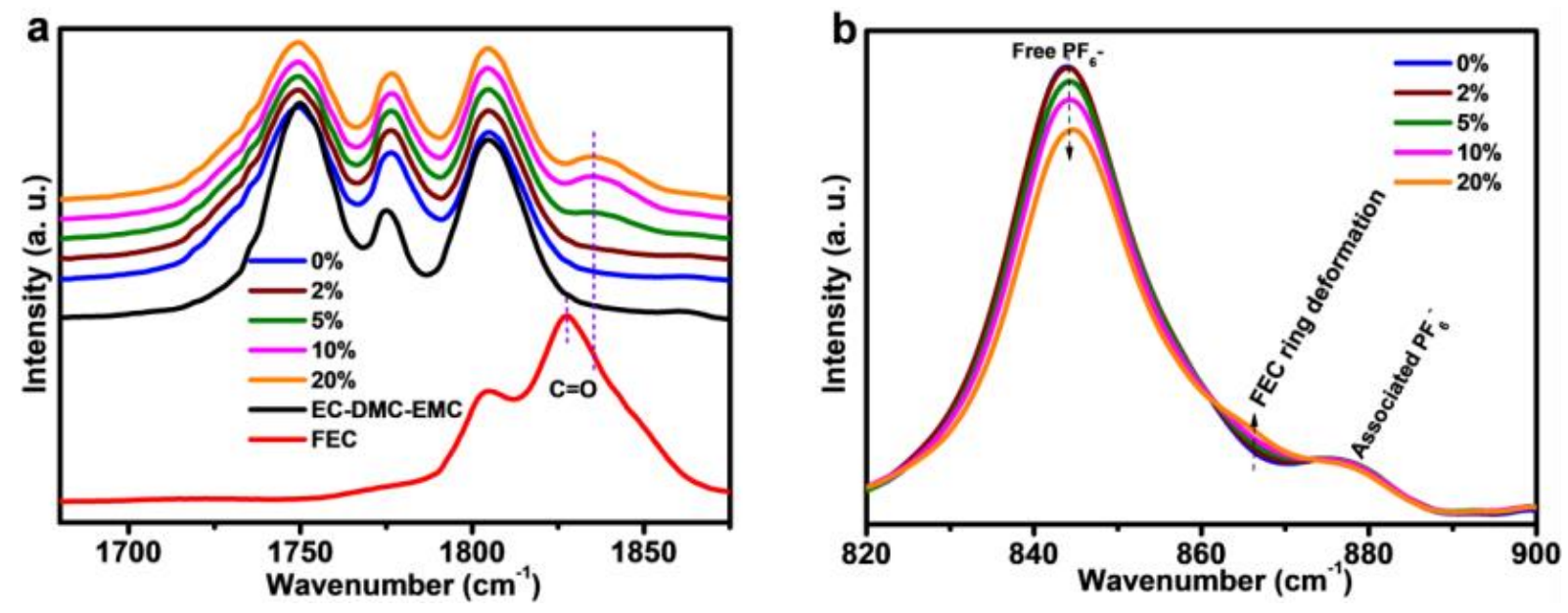

Figure S5. (a, b) FTIR spectra of electrolyte solutions with different FEC contents as compared to pure FEC and EC-DMC-EMC solvent mixture. 

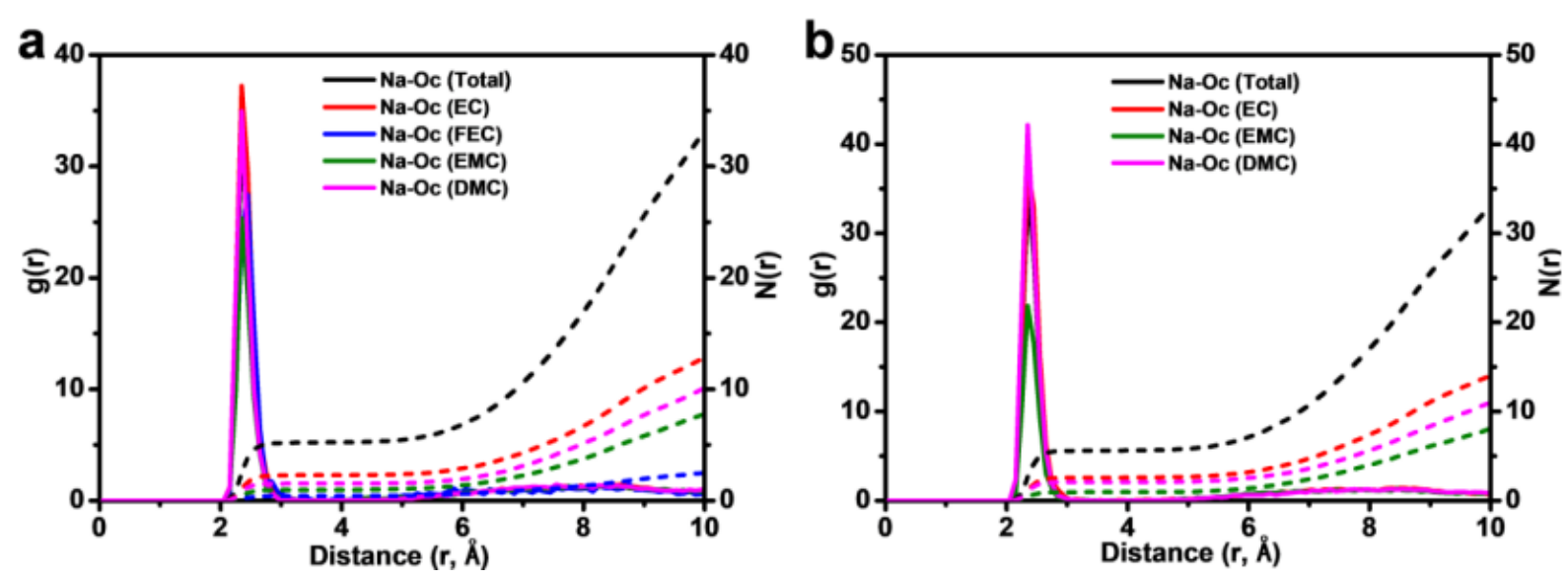

Figure S6. RDFs g(r) (solid lines) and coordination number N(r) (dash lines) of Na-Oc pairs of $1.0 \mathrm{M} \mathrm{NaPF}_{6}$ in EC-DMC-EMC (1:1:1, vol) (a) with $10 \mathrm{wt} \%$ FEC and (b) without FEC.
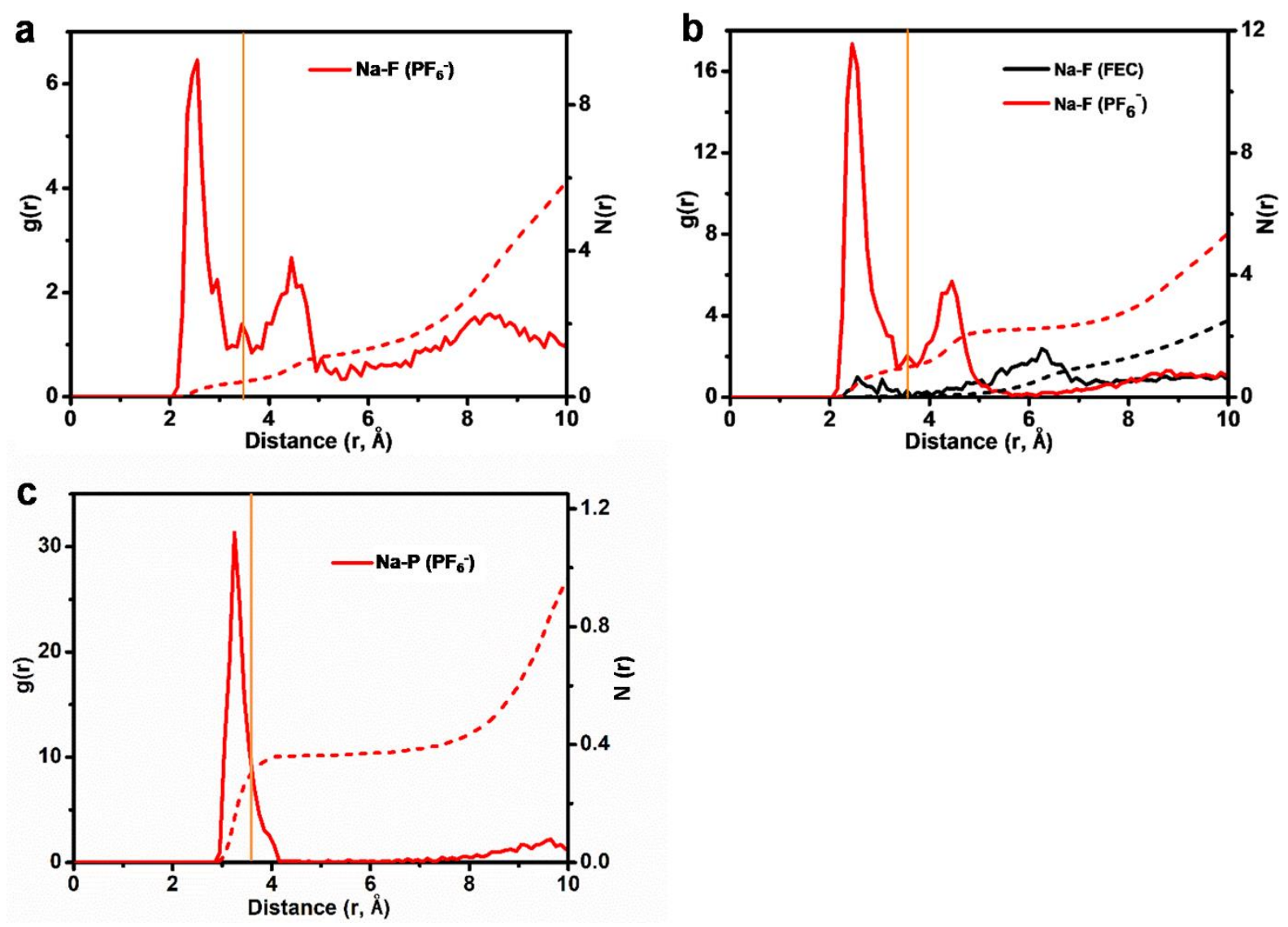

Figure S7. RDFs g(r) (solid lines) and coordination number N(r) (dash lines) of (a, b) Na-F and (c) Na-P pairs in the 1.0 $\mathrm{M} \mathrm{NaPF}_{6}$ in EC-DMC-EMC $(1: 1: 1$, vol) electrolyte (a) without and $(b, c)$ with $10 \mathrm{wt} \%$ FEC, respectively. 
a

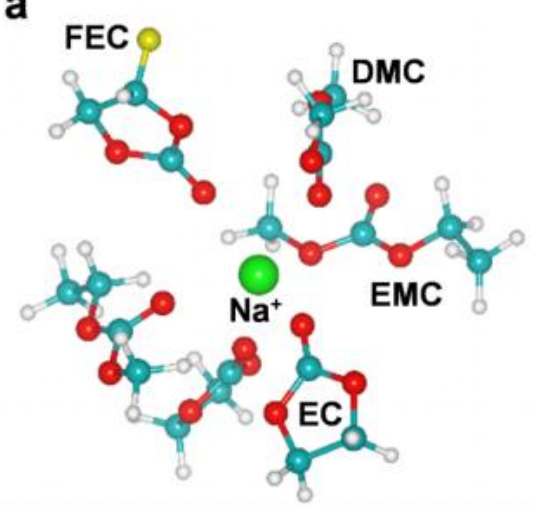

b

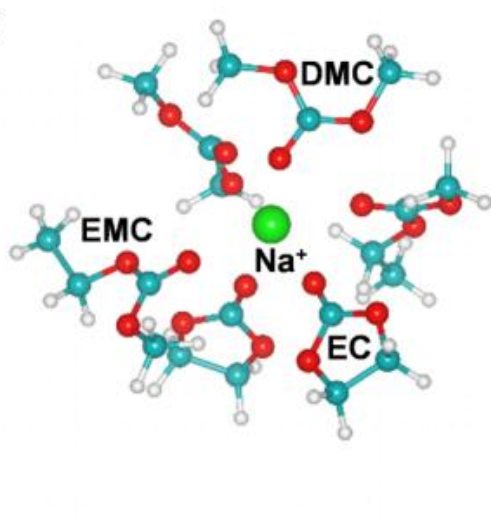

Figure S8. Representative solvation structures of $\mathrm{Na}^{+}$cations in $1.0 \mathrm{M} \mathrm{NaPF}_{6}$ in EC-DMCEMC (1:1:1, vol) (a) with $10 \mathrm{wt} \%$ FEC and (b) without FEC. Colours for different elements: Na-green, F-yellow, O-red, H-gray and C-cyan.
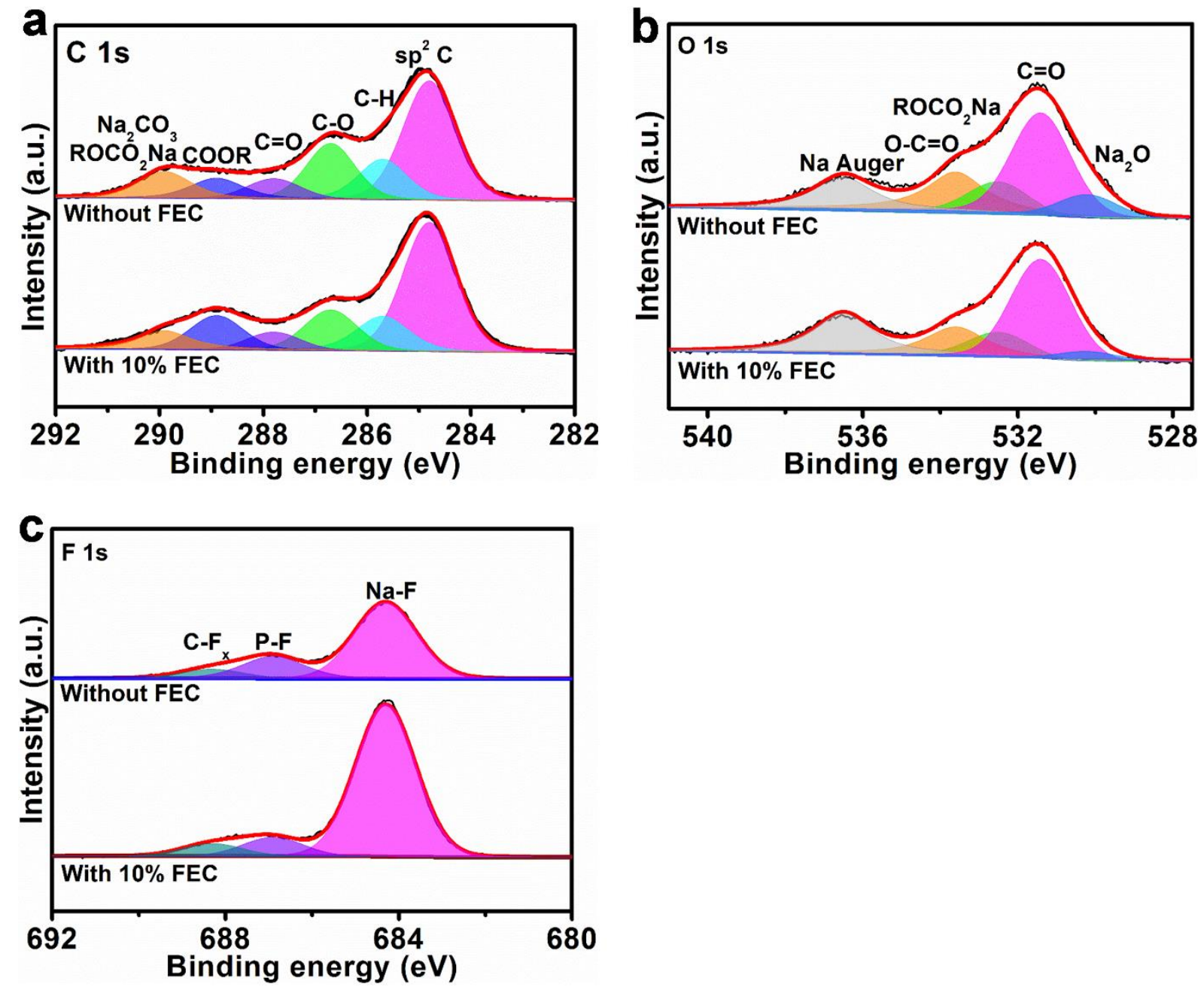

Figure S9. XPS analysis of $\mathrm{Na}$ metal anodes in $\mathrm{Na}(-) / /$ graphite $(+)$ dual-ion batteries after 10 cycles at $500 \mathrm{~mA} / \mathrm{g}$ when utilizing two $\mathrm{Na}^{+}$-based electrolytes with and without $10 \mathrm{wt} \% \mathrm{FEC}$, respectively. (a) $\mathrm{C} 1 \mathrm{~s}$, (b) $\mathrm{O} 1 \mathrm{~s}$ and (c) $\mathrm{F} 1 \mathrm{~s}$. 

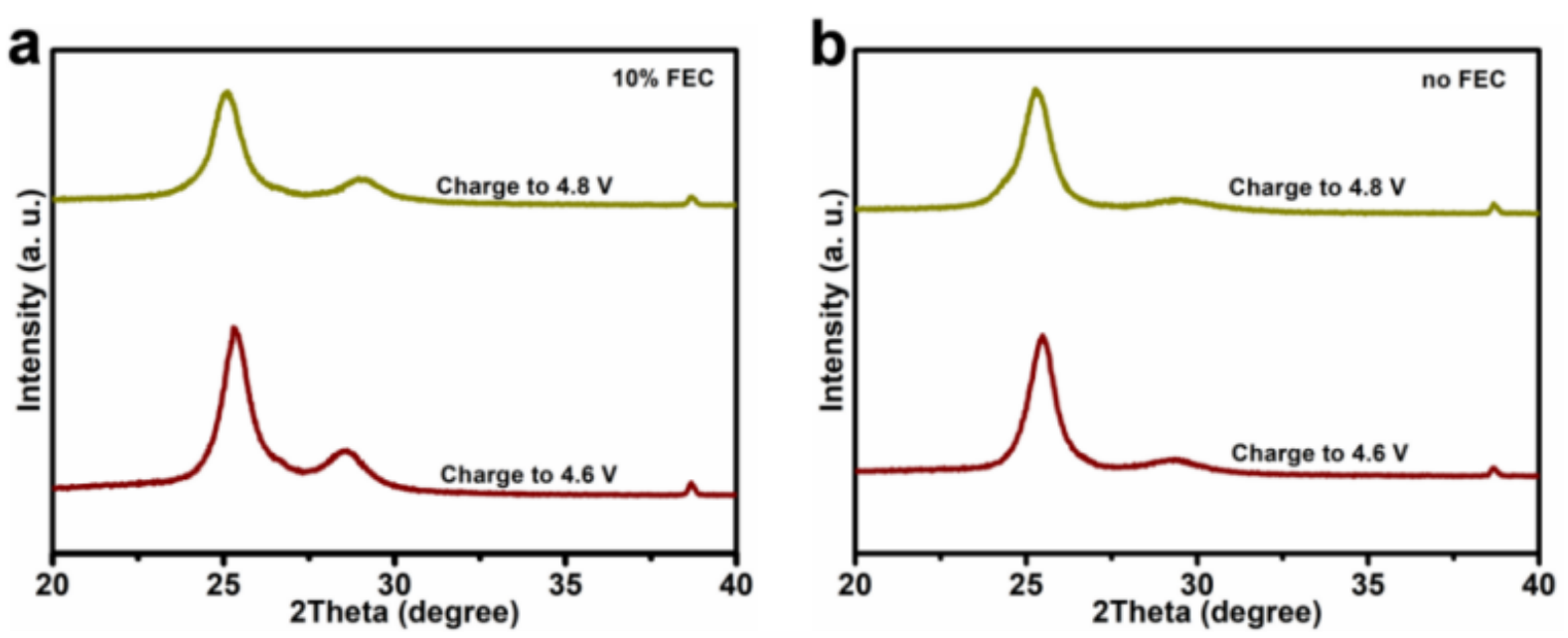

Figure S10. XRD patterns of graphite cathodes at the charge potentials of 4.6 and $4.8 \mathrm{~V}$ after 5 cycles at $50 \mathrm{~mA} / \mathrm{g}$ when utilizing two electrolytes (a) with and (b) without $10 \mathrm{wt} \% \mathrm{FEC}$, respectively.
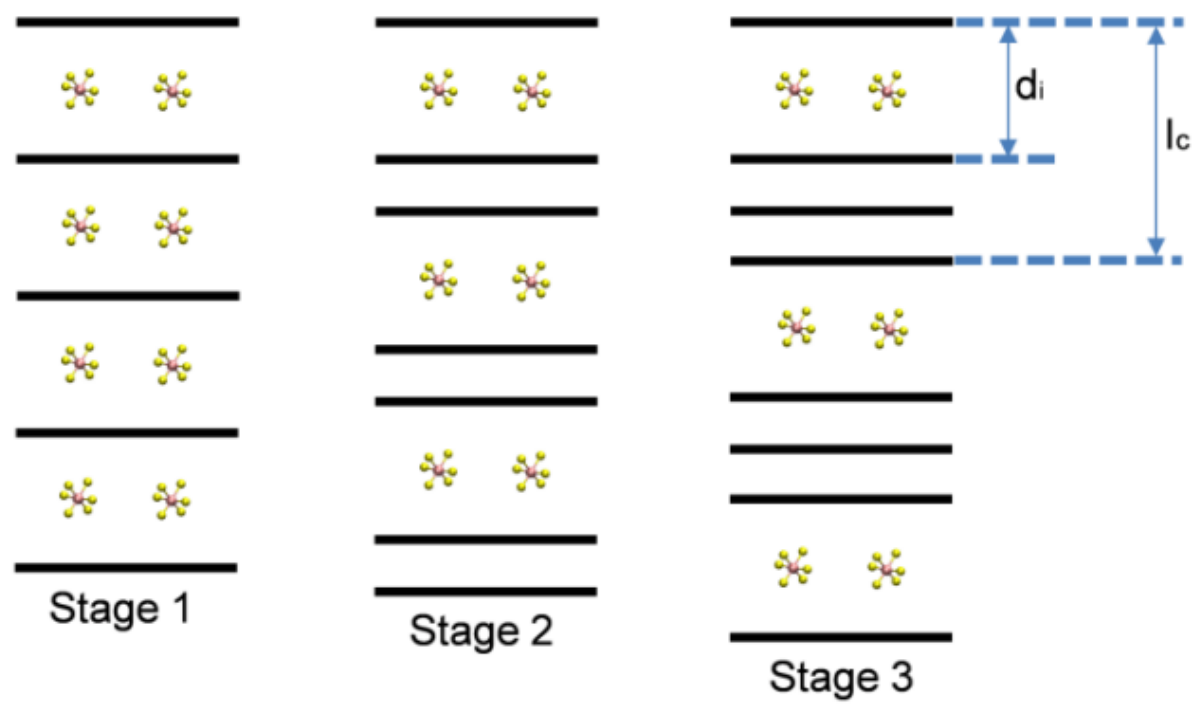

Figure S11. Schematic diagram of different stages of graphite intercalation compounds.

When $\mathrm{PF}_{6}{ }^{-}$anions are continuously inserted into graphite during the charging process, the (002) peak of graphite splits into the $(00 n+1)$ peak at the low angle and $(00 n+2)$ peak at the high angle. The plane spacing of the $(00 n+1)$ and $(00 n+2)$ planes can be calculated based on the Bragg's law:

$$
\begin{aligned}
& \mathrm{d}_{00 n+1}=\frac{\lambda}{2 \sin \theta_{00 n+1}}=\frac{I_{C}}{n+1} \\
& \mathrm{~d}_{00 n+2}=\frac{\lambda}{2 \sin \theta_{n+2}}=\frac{I_{C}}{n+2}
\end{aligned}
$$


where $I_{c}$ represents the periodic distance and $\lambda$ is the $X$-ray wavelength. Thus, the stage number (n) can be calculated to be

$$
\mathrm{n}=\frac{1}{\frac{\sin \theta_{00 x+2}-1}{\sin \theta_{00 x+1}}-1}
$$

After confirming the $(00 n+1)$ plane index, the intercalant gallery height $\left(\mathrm{d}_{\mathrm{i}}\right)$ and gallery expansion $(\Delta \mathrm{d})$ of $\mathrm{PF}_{6}$-intercalated graphite can be calculated according to the following equation:

$$
I_{C}=d_{i}+(n-1) \times 3.34=\Delta d+3.34 \times n=(n+1) \times d_{00 n+1}
$$
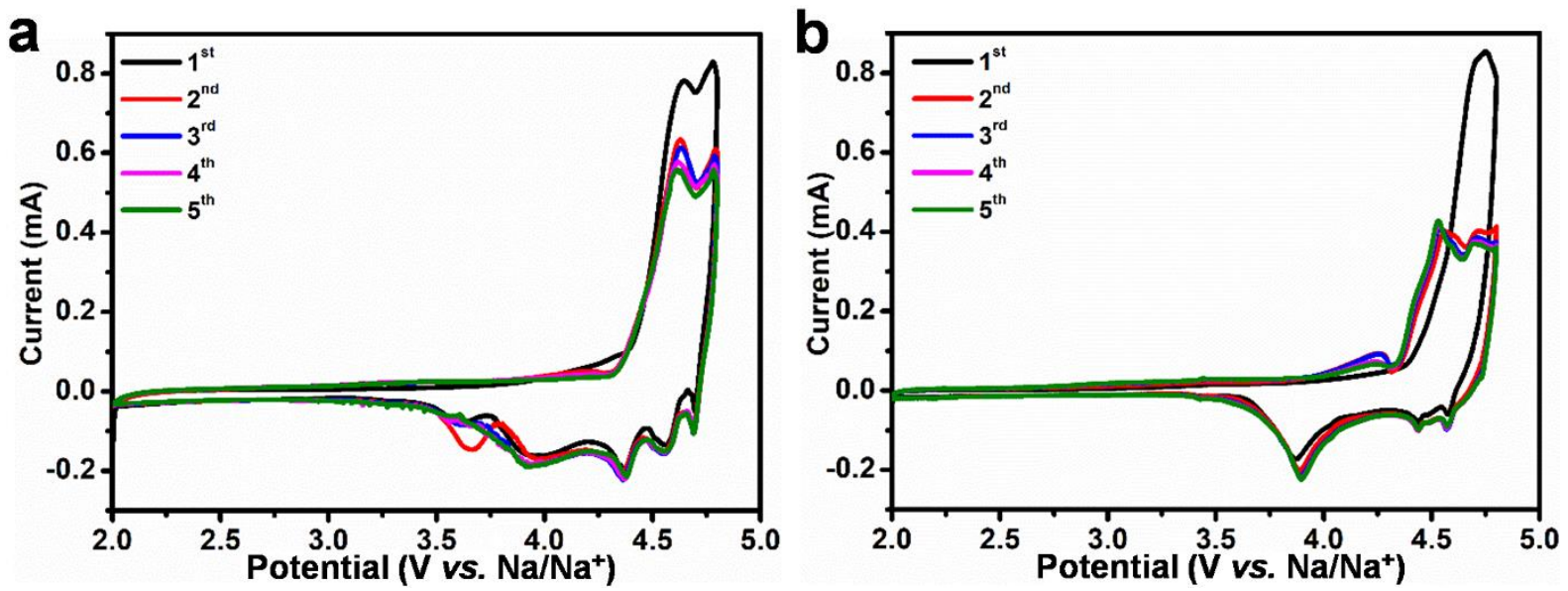

Figure S12. CV curves of graphite cathodes in two electrolytes (a) with and (b) without $10 \mathrm{wt} \%$ $\mathrm{FEC}$ at $1 \mathrm{mV} / \mathrm{s}$.
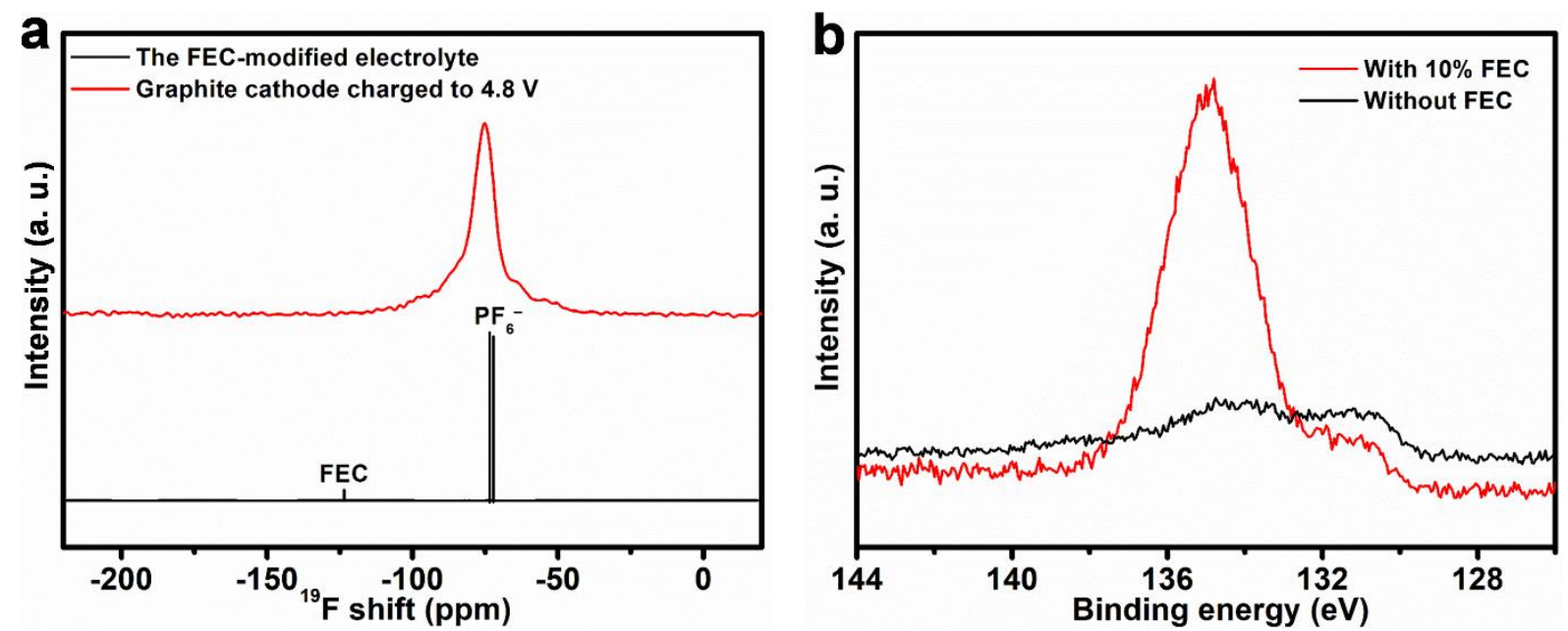

Figure S13. (a) Chemical shifts of ${ }^{19} \mathrm{~F}$ NMR spectra of the FEC-containing electrolyte and the graphite cathode at a full charge state of $\mathrm{Na}(-) / /$ graphite $(+)$ batteries with the FEC-containing 
electrolyte. (b) P 2p spectra of graphite cathodes charged to $4.8 \mathrm{~V}$ in $\mathrm{Na}(-) / /$ graphite(+) batteries with two different electrolytes collected by XPS spectroscopy after deep etching of $50 \mathrm{~nm}$.

The presence of a broad ${ }^{19} \mathrm{~F}$ NMR peak (Figure S13a) ranging from -100 to $-50 \mathrm{ppm}$ demonstrates the intercalation of $\mathrm{PF}_{6}{ }^{-}$anions into the graphite cathode at a full charge state when utilizing the FEC-modified electrolyte. Notably, with the addition of FEC, much strong peak can be observed from P 2p spectra of graphite cathodes (Figure S13b) charged to $4.8 \mathrm{~V}$ collected by XPS spectroscopy after deep etching of $50 \mathrm{~nm}$, suggesting much more intercalation of $\mathrm{PF}_{6}{ }^{-}$anions into graphite cathodes when FEC appears, which is also consistent with the large interplanar spacing of graphite obtained from the HRTEM image (Figure 4c).
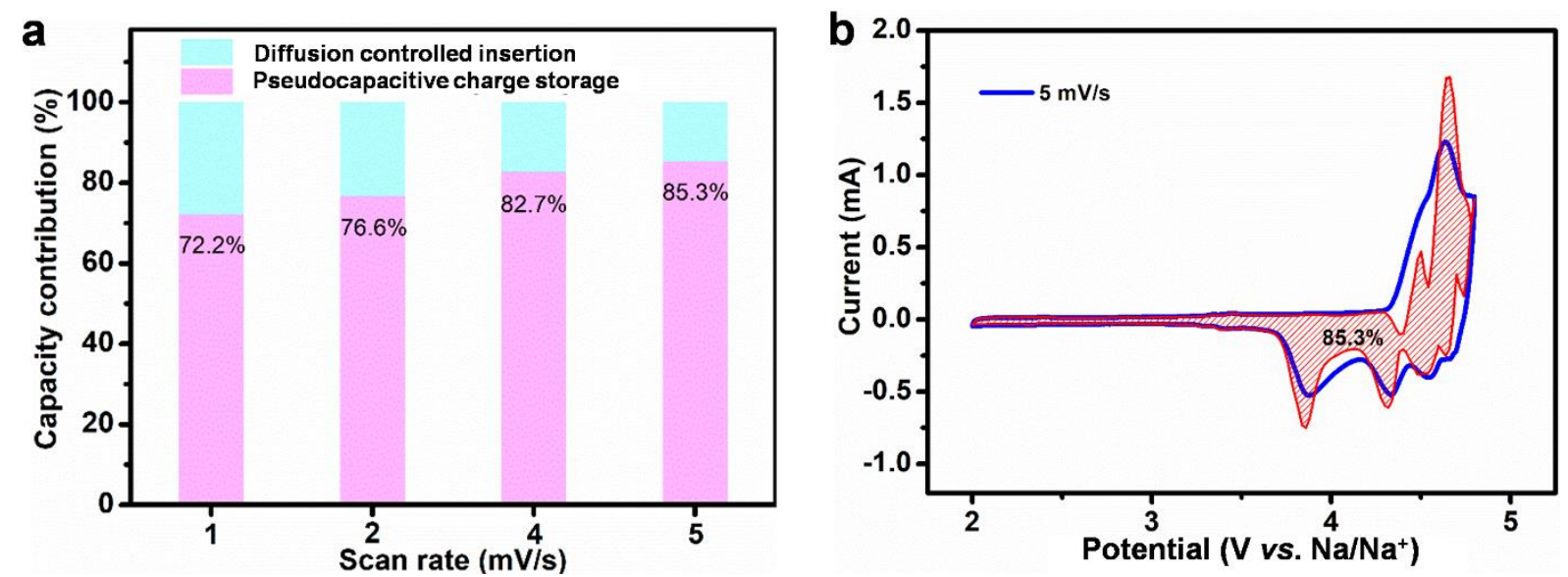

Figure S14. (a) The capacitive contribution ratio of graphite cathode at different scan rates and (b) CV curve of graphite cathode with the capacitive contribution shown in the red region at 5 $\mathrm{mV} / \mathrm{s}$ when utilizing the $10 \mathrm{wt} \%$ FEC-modified electrolyte.

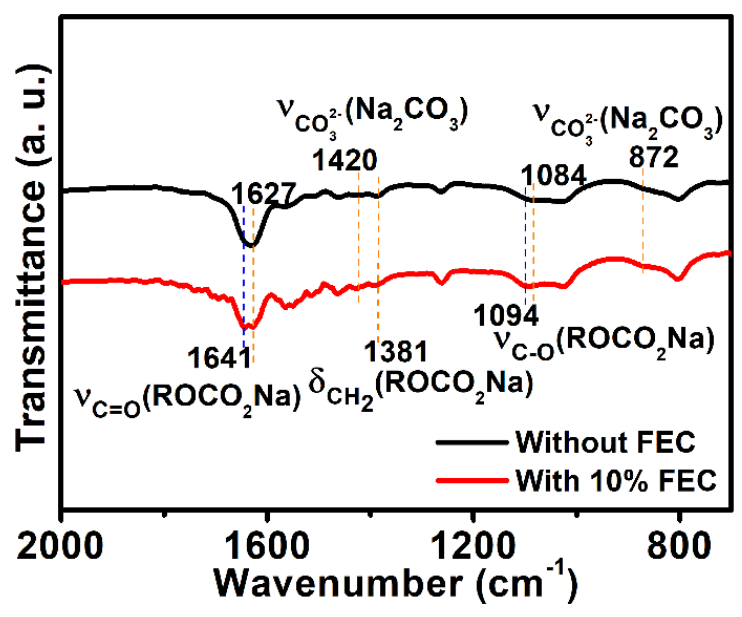

Figure S15. FTIR spectra of graphite cathodes after 10 cycles in two electrolytes with and without $10 \%$ FEC, respectively. 


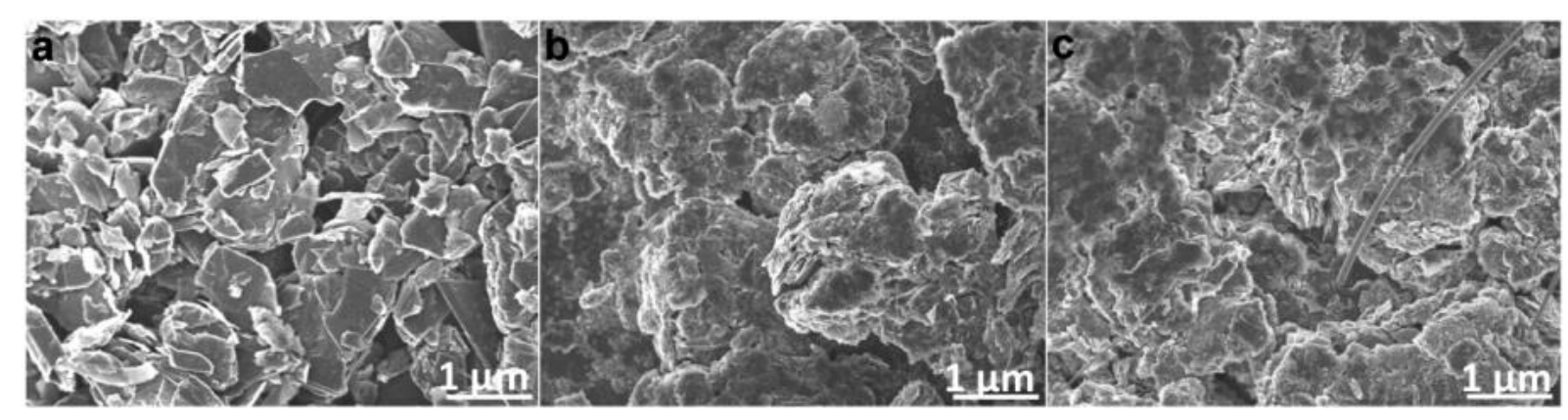

Figure S16. SEM images of the (a) initial graphite and graphite cathodes after 500 cycles at $500 \mathrm{~mA} / \mathrm{g}$ in two electrolytes (b) with and (c) without $10 \mathrm{wt} \% \mathrm{FEC}$, respectively.

a

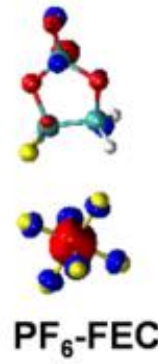

b

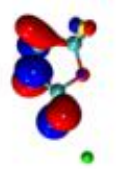

Na-FEC
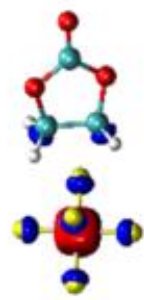

$\mathrm{PF}_{6}$-EC

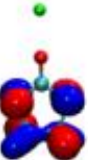

$\mathrm{Na}-\mathrm{EC}$

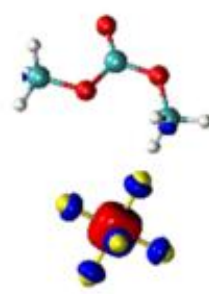

$\mathrm{PF}_{6}$-DMC

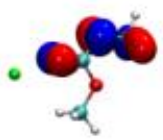

Na-DMC
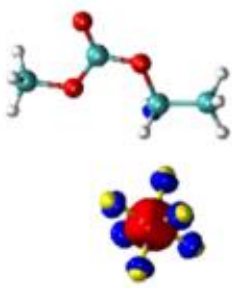

$\mathrm{PF}_{6}$-EMC

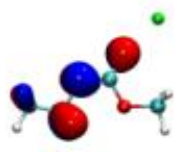

$\mathrm{Na}-\mathrm{EMC}$

Figure S17. (a) LUMO states of anion-solvent complexes and (b) HOMO states of cationsolvent complexes simulated by DFT calculations. 

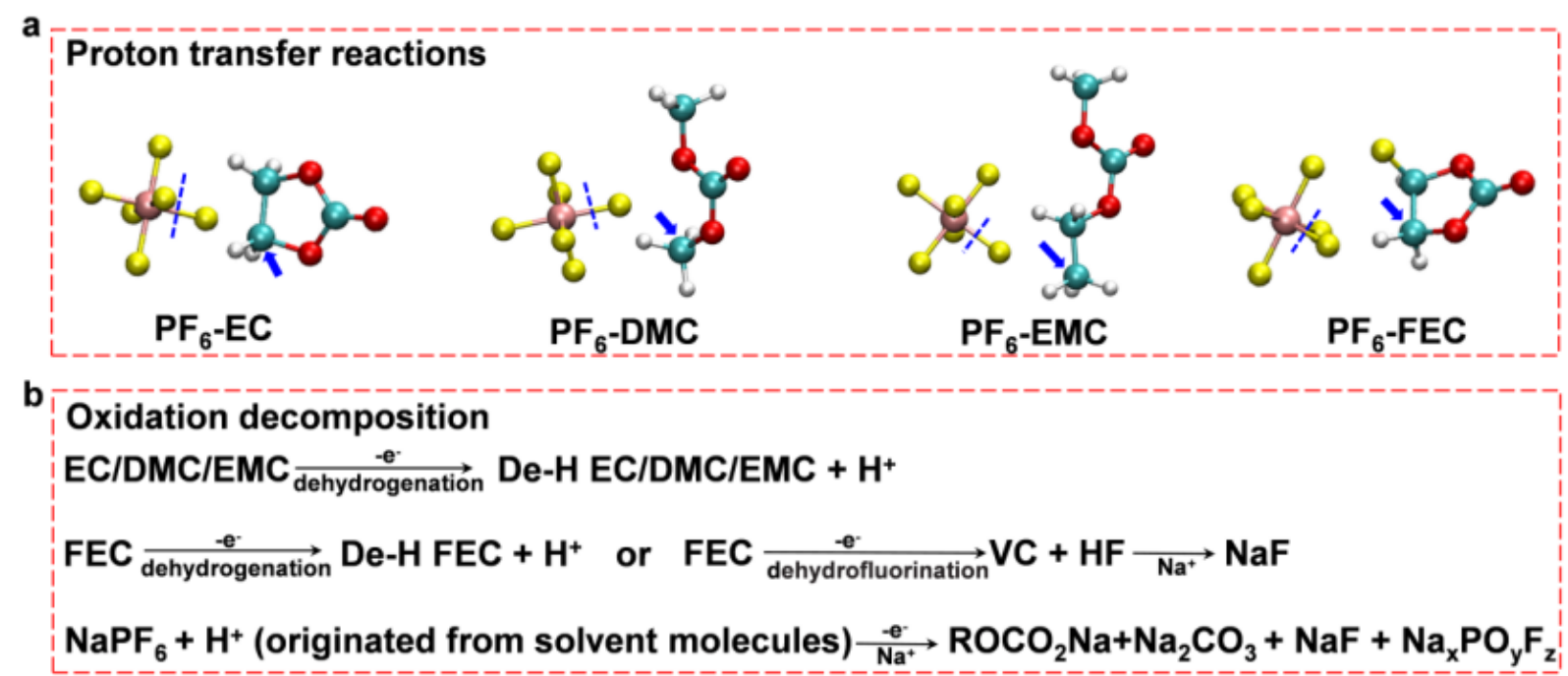

Figure S18. (a) The snapshots of anion-solvent complexes with proton transfer reactions and (b) possible oxidation decomposition reactions of the FEC-modified electrolyte. The blue arrows indicate the active sites of dehydrogenation and the blue dash lines represent P-F bond breakage.

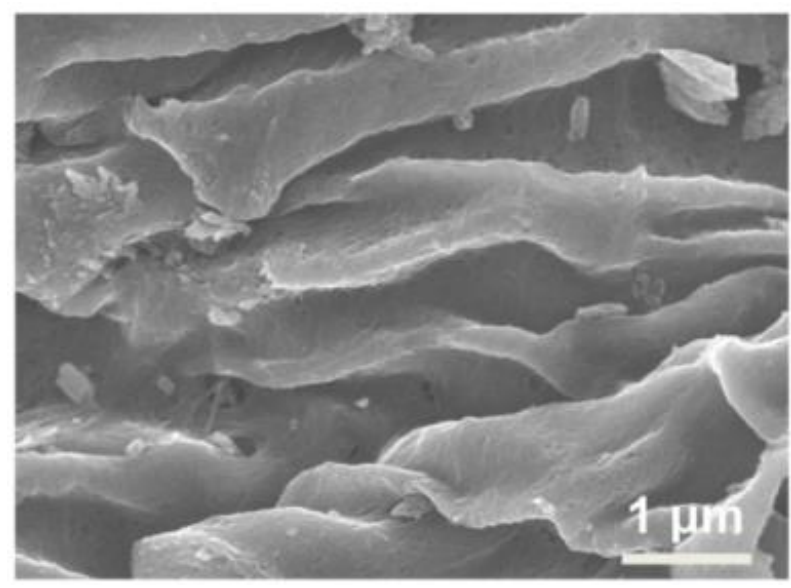

Figure S19. The SEM image of NCF. 


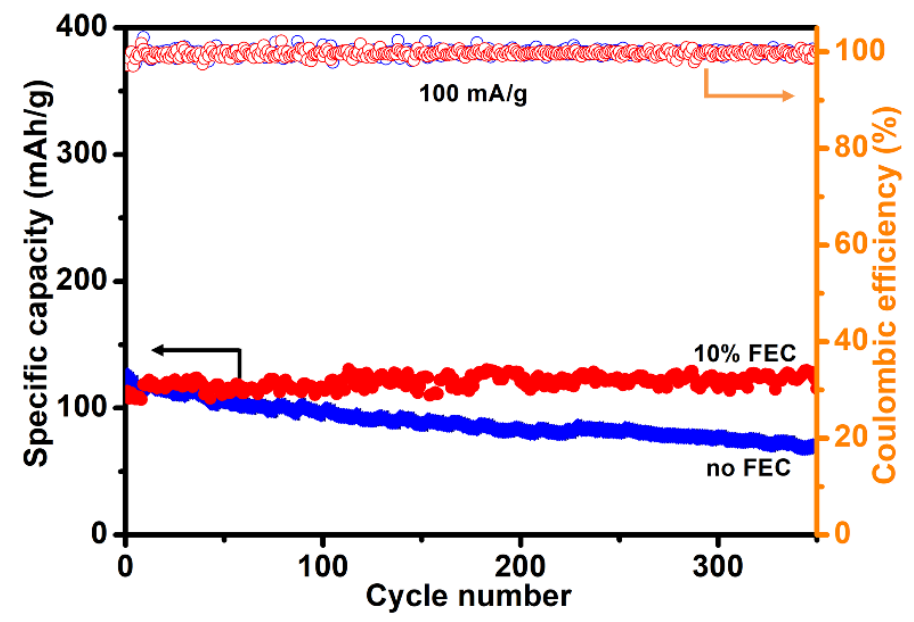

Figure S20. Cycling performance of NCF anode in half cells with two electrolytes containing $10 \%$ and $0 \%$ FEC, respectively.
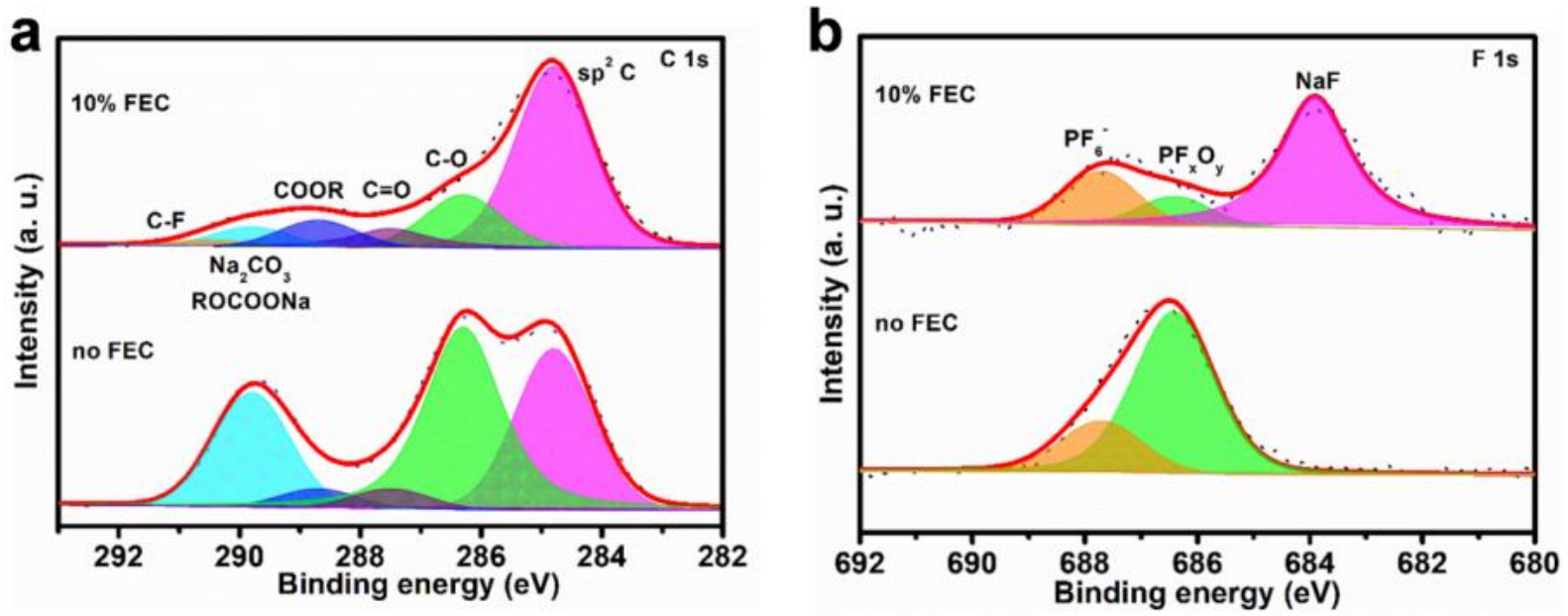

Figure S21. XPS analysis of NCF electrodes in half cells after 5 cycles discharged to $0.01 \mathrm{~V}$ when utilizing two electrolytes with and without $10 \mathrm{wt} \% \mathrm{FEC}$, respectively. (a) $\mathrm{C} 1 \mathrm{~s}$ and (b) F 1 s. 
Table S1. Electrochemical performance of anion-insertion cathodes.

\begin{tabular}{|c|c|c|c|c|c|c|}
\hline $\begin{array}{c}\text { Battery } \\
\text { configuration }\end{array}$ & $\begin{array}{l}\text { Electrolyte } \\
\text { composition }\end{array}$ & $\begin{array}{l}\text { Potential } \\
\text { window } \\
\text { (V) }\end{array}$ & $\begin{array}{l}\text { Current } \\
\text { density } \\
(\mathrm{mA} / \mathrm{g})\end{array}$ & $\begin{array}{c}\text { Cycle } \\
\text { number } \\
\text { (n) }\end{array}$ & $\begin{array}{l}\text { Capacity } \\
\text { retention } \\
(\%)\end{array}$ & Ref. \\
\hline $\begin{array}{l}\text { Li//SEI-modified } \\
\text { graphite }\end{array}$ & $1 \mathrm{M} \mathrm{LiPF}_{6} / \mathrm{EMC}$ & $3.0-5.0$ & 200 & 500 & 97.5 & 17 \\
\hline $\mathrm{Na} / /$ Graphite & 1:2 NaTFSI:TMP & $3.0-4.8$ & 500 & 750 & 72 & 20 \\
\hline Li//MCMB 10-28 & $\begin{array}{l}\text { 1.7 M LiPF } 6 / \text { FEC-EMC } \\
(4: 6 \mathrm{w} / \mathrm{w})+5 \mathrm{mM} \text { HFIP }\end{array}$ & $4.0-5.2$ & $\mathrm{C} / 14$ & 220 & 85.4 & 15 \\
\hline $\mathrm{Na} / /$ Graphene & $\begin{array}{l}2 \mathrm{M} \mathrm{NaPF}_{6} / \mathrm{DEGDME} \\
\text { with } 1 \%\left(\mathrm{C}_{3} \mathrm{HF}_{6} \mathrm{O}\right)_{3} \mathrm{PO}\end{array}$ & $2.0-5.0$ & 100 & 250 & 75 & 22 \\
\hline K//Graphite & $\begin{array}{c}\operatorname{Pyr}_{14} \text { TFSI }+0.3 \text { M KTFSI } \\
+2 \mathrm{wt} \% \mathrm{ES}\end{array}$ & $3.4-5.0$ & 50 & 100 & 95.7 & 21 \\
\hline Li//Graphite & $\begin{array}{c}\operatorname{Pyr}_{14} \text { TFSI, } 1 \text { M LiTFSI }+ \\
2 \mathrm{wt} \% \mathrm{ES}\end{array}$ & $3.0-5.0$ & 50 & 500 & 94 & 19 \\
\hline $\mathrm{Li} / /$ Coronene & $1 \mathrm{M} \mathrm{LiPF}_{6} / \mathrm{EC}+\mathrm{DEC}$ & $2.5-4.2$ & 20 & 960 & 92 & 23 \\
\hline $\mathrm{Na} / / \mathrm{Fe}_{2}(\mathrm{dobpdc})$ & $\begin{array}{c}0.6 \mathrm{M} \mathrm{NaPF}_{6} / \mathrm{EC}+\mathrm{DMC} \\
(30: 70)\end{array}$ & $2.0-3.65$ & 140 & 50 & 94 & 24 \\
\hline $\mathrm{Na} / /$ Coronene & $1 \mathrm{M} \mathrm{NaPF}_{6} / \mathrm{EC}+\mathrm{DEC}$ & $2.5-4.0$ & 20 & 1000 & 85 & 25 \\
\hline $\mathrm{Li} / / \mathrm{Li}_{2} \mathrm{DAnT}$ & $1 \mathrm{M} \mathrm{LiClO}_{4} / \mathrm{PC}$ & $2.8-3.5$ & 15 & 20 & 87.2 & 26 \\
\hline K//Graphite & $5 \mathrm{M} \mathrm{KFSI/EC/DMC}$ & $3.2-5.25$ & 100 & 300 & 88.9 & 18 \\
\hline $\mathrm{Li} / / \mathrm{DARb}$ & $1 \mathrm{M} \mathrm{LiPF}_{6} / \mathrm{EC}-\mathrm{DMC}$ & $2.0-4.0$ & & 60 & 65.2 & 27 \\
\hline K//PTPAn & $0.8 \mathrm{M} \mathrm{KPF}_{6} / \mathrm{EC}+\mathrm{DEC}$ & $2.0-4.0$ & 100 & 60 & 71 & 28 \\
\hline $\begin{array}{l}\text { Li//LTO-modified } \\
\text { graphite }\end{array}$ & $\begin{array}{c}\text { 1.0 } \mathrm{M} \mathrm{LiPF}_{6} \text { in } \mathrm{EMC} / \mathrm{SL} \\
(1: 4, \text { vol:vol })\end{array}$ & $3.0-5.4$ & 1860 & 2000 & 85.1 & 16 \\
\hline $\mathrm{Na} / /$ Graphite & gel polymer electrolyte & $3.0-5.0$ & 100 & 1000 & 86.7 & 14 \\
\hline $\mathrm{Na} / /$ Graphite & $\begin{array}{c}1 \mathrm{M} \mathrm{NaPF}_{6} / \mathrm{EC} \mathrm{DMC}- \\
\operatorname{EMC}(1: 1: 1)+10 \mathrm{wt} \% \text { FEC }\end{array}$ & $2.0-4.8$ & $\begin{array}{r}500 \\
1000\end{array}$ & $\begin{array}{l}1000 \\
4000\end{array}$ & 98.3 & $\begin{array}{l}\text { This } \\
\text { work }\end{array}$ \\
\hline
\end{tabular}

Gel polymer electrolyte (GPE), ${ }^{14}$ mesocarbon microbeads (MCMB), ${ }^{15,16} \mathrm{Li}_{4} \mathrm{Ti}_{5} \mathrm{O}_{12}$ (LTO), ${ }^{16} \quad 4,4^{\prime}-$ dioxidobiphenyl-3,3-dicarboxylate (dobpdc $\left.{ }^{4-}\right),{ }^{24}$ dilithium 2,5-(dianilino) terephthalate $\left(\operatorname{Li}_{2} \mathrm{DAnT}\right),{ }^{26}$ 5,12diaminorubicene (DARb), ${ }^{27}$ and polytriphenylamine (PTPAn). ${ }^{28}$ 
Table S2. The calculated coordination number of Na-Oc and F-H pairs of $1.0 \mathrm{M} \mathrm{NaPF}_{6}$ in ECDMC-EMC and $1 \mathrm{M} \mathrm{NaPF}_{6}$ in EC-DMC-EMC with $10 \mathrm{wt} \%$ FEC.

\begin{tabular}{cccccccccccc}
\hline & \multicolumn{8}{c}{ Coordination number } \\
\cline { 2 - 10 } Electrolyte & \multicolumn{8}{c}{ Na-Oc } & & \multicolumn{7}{c}{ F-H } \\
\cline { 2 - 10 } & EC & EMC & DMC & FEC & Total & EC & EMC & DMC & FEC & Total \\
\hline Without FEC & 2.58 & 0.96 & 2.08 & - & 5.62 & 3.53 & 2.26 & 2.55 & - & 8.24 \\
$\begin{array}{c}\text { With 10\% } \\
\text { FEC }\end{array}$ & 2.30 & 0.95 & 1.53 & 0.42 & 5.21 & 3.22 & 1.98 & 2.68 & 0.59 & 8.47 \\
\hline
\end{tabular}

Table S3. Calculated cation-solvent and anion-solvent binding energy.

\begin{tabular}{cccc}
\hline Cation-solvent & Binding energy (kcal/mol) & Anion-solvent & Binding energy (kcal/mol) \\
\hline $\mathrm{Na}^{+}-\mathrm{EC}$ & -13.1094 & $\mathrm{PF}_{6}^{-}-\mathrm{EC}$ & -2.8484 \\
$\mathrm{Na}^{+}-\mathrm{DMC}$ & -14.2594 & $\mathrm{PF}_{6}^{-}-\mathrm{DMC}$ & -1.3965 \\
$\mathrm{Na}^{+}-\mathrm{EMC}$ & -14.5390 & $\mathrm{PF}_{6}^{-}-\mathrm{EMC}$ & -1.9075 \\
$\mathrm{Na}^{+}-\mathrm{FEC}$ & -11.5239 & $\mathrm{PF}_{6}^{-}-\mathrm{FEC}$ & -2.7164 \\
\hline
\end{tabular}

Table S4. XRD data and calculated values for $\mathrm{PF}_{6}$-intercalated graphite at the charge potentials of 4.6 and $4.8 \mathrm{~V}$.

\begin{tabular}{cccccccc}
\hline Electrolyte & Potential $(\mathbf{V})$ & $\mathbf{2 \Theta}_{\mathbf{n}+\mathbf{1}}\left({ }^{\circ}\right)$ & $\mathbf{2 \Theta}_{\mathbf{n}+\mathbf{2}}\left(^{\circ}\right)$ & $\mathbf{n}$ & $\mathbf{I c}(\AA)$ & $\mathbf{d}_{\mathbf{i}}(\boldsymbol{\AA})$ & $\Delta \mathbf{d}(\mathbf{\AA})$ \\
\hline $\begin{array}{c}10 \mathrm{wt} \% \\
\text { FEC }\end{array}$ & 4.6 & 25.32 & 28.58 & 7 & 28.10 & 8.07 & 4.73 \\
\hline Without & 4.8 & 25.11 & 29.12 & 5 & 21.25 & 7.89 & 4.55 \\
FEC & 4.6 & 25.51 & 29.32 & 6 & 24.41 & 7.71 & 4.37 \\
& 4.8 & 25.30 & 29.48 & 5 & 21.10 & 7.74 & 4.40 \\
\hline
\end{tabular}


Table S5. HOMO and LUMO energy levels of individual solvent and $\mathrm{NaPF}_{6}$ species, and cation/anion-solvent complexes.

\begin{tabular}{|c|c|c|c|}
\hline Molecule & $\mathrm{E}_{\text {номо }}(\mathrm{eV})$ & $E_{\text {LUMo }}(\mathrm{eV})$ & $E_{\text {Gap }}(\mathrm{eV})$ \\
\hline FEC & -8.80 & 0.076 & 8.876 \\
\hline $\mathrm{EC}$ & -8.37 & 0.099 & 8.469 \\
\hline DMC & -8.15 & 0.249 & 8.399 \\
\hline EMC & -8.09 & 0.009 & 8.099 \\
\hline $\mathrm{NaPF}_{6}$ & -10.61 & -0.93 & 9.68 \\
\hline Na-FEC & -9.61 & -1.04 & 8.57 \\
\hline Na-EC & -9.00 & -1.00 & 8.00 \\
\hline Na-DMC & -9.02 & -0.99 & 8.03 \\
\hline Na-EMC & -8.86 & -0.98 & 7.88 \\
\hline $\mathrm{PF}_{6}$-FEC & -8.66 & 0.031 & 8.691 \\
\hline $\mathrm{PF}_{6}-\mathrm{EC}$ & -8.24 & 0.051 & 8.291 \\
\hline $\mathrm{PF}_{6}-\mathrm{DMC}$ & -8.02 & 0.031 & 8.051 \\
\hline $\mathrm{PF}_{6}-\mathrm{EMC}$ & -7.97 & 0.033 & 8.003 \\
\hline
\end{tabular}

\section{REFERENCES}

(1) Frisch M. J.; Trucks G. W.; Schlegel H. B.; Scuseria G. E.; Robb M. A.; Cheeseman J. R.; Scalmani G.; Barone V.; Mennucci B.; Petersson G. A.; Nakatsuji H.; Caricato M.; Li X.; Hratchian H. P.; Izmaylov A. F.; Bloino J.; Zheng G.; Sonnenberg J. L.; Hada M.; Ehara M.; Toyota K.; Fukuda R.; Hasegawa J.; Ishida M.; Nakajima T.; Honda Y.; Kitao O.; Nakai H.; Vreven T.; Montgomery J. A.; Jr.; Peralta J. E.; Ogliaro F.; Bearpark M.; Heyd J. J.; Brothers E.; Kudin K. N.; Staroverov V. N.; Keith T.; Kobayashi R.; Normand J.; Raghavachari K.; Rendell A.; Burant J. C.; Iyengar S. S.; Tomasi J.; Cossi M.; Rega N.; Millam J. M.; Klene M.; Knox J. E.; Cross J. B.; Bakken V.; Adamo C.; Jaramillo J.; Gomperts R.; Stratmann R. E.; Yazyev O.; Austin A. J.; Cammi R.; Pomelli C.; Ochterski J. W.; Martin R. L.; Morokuma K.; 
Zakrzewski V. G.; Voth G. A.; Salvador P.; Dannenberg J. J.; Dapprich S.; Daniels A. D.; Farkas O.; Foresman J. B.; Ortiz J. V.; Cioslowski J.; Fox D. J. Gaussian 09, Revision D.01, Gaussian Inc. Wallingford CT, 2013.

(2) Lu T.; Chen F. Multiwfn: A Multifunctional Wavefunction Analyzer. J. Comput. Chem. 2012, 33, 580-592.

(3) Humphrey W.; Dalke A.; Schulten K. VMD: Visual Molecular Dynamics. J. Mol. Graph. 1996, 14, 33-38.

(4) Abraham M. J.; Murtola T.; Schulz R.; Páll S.; Smith J. C.; Hess B.; Lindahl E. GROMACS: High Performance Molecular Simulations Through Multi-Level Parallelism from Laptops to Supercomputers. SoftwareX 2015, 1-2, 19-25.

(5) Páll S.; Abraham M. J.; Kutzner C.; Hess B.; Lindahl E. Tackling Exascale Software Challenges in Molecular Dynamics Simulations with GROMACS In S. Markidis \& E. Laure (Eds.). Solving Software Challenges for Exascale 2015, 8759, 3-27.

(6) Pronk S.; Páll S.; Schulz R.; Larsson P.; Bjelkmar P.; Apostolov R.; Shirts M. R.; Smith J. C.; Kasson P. M.; van der Spoel D.; Hess B.; Lindahl E. GROMACS 4.5: A High-Throughput and Highly Parallel Open Source Molecular Simulation Toolkit. Bioinformatics 2013, 29, 845-854.

(7) Hess B.; Kutzner C.; van der Spoel D.; Lindahl E. GROMACS 4: Algorithms for Highly Efficient, Load-Balanced, and Scalable Molecular Simulation. J. Chem. Theory Comput. 2008, 4, 435-447.

(8) van der Spoel D.; Lindahl E.; Hess B.; Groenhof G.; Mark A. E.; Berendsen H. J. C. GROMACS: Fast, Flexible and Free. J. Comp. Chem. 2005, 26, 1701-1719.

(9) Lindahl E.; Hess B.; van der Spoel D. GROMACS 3.0: A Package for Molecular Simulation and Trajectory Analysis. J. Mol. Mod. 2001, 7, 306-317. 
(10) Berendsen H. J. C.; van der Spoel D.; van Drunen R. GROMACS: A MessagePassing Parallel Molecular Dynamics Implementation. Comp. Phys. Comm. 1995, 91, 43-56.

(11) Lindahl, Abraham, Hess, van der Spoel, 2019, DOI: 10.5281/zenodo.3460414.

(12) Jorgensen W. L. Optimized Intermolecular Potential Functions for Liquid Alcohols. J. Phys. Chem. 1986, 90, 1276-1284.

(13) Martínez L.; Andrade R.; Birgin E. G.; Martínez J. M. Software News and Update Packmol: A Package for Building Initial Configurations for Molecular Dynamics Simulations. J. Comput. Chem. 2009, 30, 2157-2164.

(14) Xu X.; Lin K.; Zhou D.; Liu Q.; Qin X.; Wang S.; He S.; Kang F.; Li B.; Wang G. Quasi-Solid-State Dual-Ion Sodium Metal Batteries for Low-Cost Energy Storage. Chem 2020, 6, 902-918.

(15) Read J. A.; Cresce A. V.; Ervin M. H.; Xu K. Dual-Graphite Chemistry Enabled by a High Voltage Electrolyte. Energy Environ. Sci. 2014, 7, 617-620.

(16) Han X.; Xu G.; Zhang Z.; Du X.; Han P.; Zhou X.; Cui G.; Chen L. An In Situ Interface Reinforcement Strategy Achieving Long Cycle Performance of Dual-Ion Batteries. Adv. Energy Mater. 2019, 9, 1804022.

(17) Li W. H.; Ning Q. L.; Xi X. T.; Hou B. H.; Guo J. Z.; Yang Y.; Chen B.; Wu X. L. Highly Improved Cycling Stability of Anion De-/Intercalation in the Graphite Cathode for Dual-Ion Batteries. Adv. Mater. 2019, 31, 1804766.

(18) Kravchyk K. V.; Bhauriyal P.; Piveteau L.; Guntlin C. P.; Pathak B.; Kovalenko M. V. High-Energy-Density Dual-Ion Battery for Stationary Storage of Electricity using Concentrated Potassium Fluorosulfonylimide. Nat. Commun. 2018, 9, 4469.

(19) Rothermel S.; Meister P.; Schmuelling G.; Fromm O.; Meyer H.-W.; Nowak S.; Winter M.; Placke T. Dual-Graphite Cells Based on the Reversible Intercalation of 
Bis(trifluoromethanesulfonyl)imide Anions from an Ionic Liquid Electrolyte. Energy Environ. Sci. 2014, 7, 3412-3423.

(20) Jiang X.; Liu X.; Zeng Z.; Xiao L.; Ai X.; Yang H.; Cao Y. A Nonflammable $\mathrm{Na}^{+}-$ Based Dual-Carbon Battery with Low-Cost, High Voltage, and Long Cycle Life. $A d v$. Energy Mater. 2018, 8, 1802176.

(21) Beltrop K.; Beuker S.; Heckmann A.; Winter M.; Placke T. Alternative Electrochemical Energy Storage: Potassium-Based Dual-Graphite Batteries. Energy Environ. Sci. 2017, 10, 2090-2094.

(22) Wang F.; Liu Z.; Zhang P.; Li H.; Sheng W.; Zhang T.; Jordan R.; Wu Y.; Zhuang X.; Feng X. Dual-Graphene Rechargeable Sodium Battery. Small 2017, 13, 1702449.

(23) Rodríguez-Pérez I. A.; Jian Z.; Waldenmaier P. K.; Palmisano J. W.; Chandrabose R. S.; Wang X.; Lerner M. M.; Carter R. G.; Ji X. A Hydrocarbon Cathode for DualIon Batteries. ACS Energy Lett. 2016, 1, 719-723.

(24) Aubrey M. L.; Long J. R. A Dual-Ion Battery Cathode via Oxidative Insertion of Anions in a Metal-Organic Framework. J. Am. Chem. Soc. 2015, 137, 13594-13602.

(25) Dong S.; Li Z.; Rodríguez-Pérez I. A.; Jiang H.; Lu J.; Zhang X.; Ji X. A Novel Coronene// $\mathrm{Na}_{2} \mathrm{Ti}_{3} \mathrm{O}_{7}$ Dual-Ion Battery. Nano Energy 2017, 40, 233-239.

(26) Deunf É.; Moreau P.; Quarez É.; Guyomard D.; Dolhem F.; Poizot P. Reversible Anion Intercalation in A Layered Aromatic Amine: A High-Voltage Host Structure for Organic Batteries. J. Mater. Chem. A 2016, 4, 6131-6139.

(27) Deunf É.; Jiménez P.; Guyomard D.; Dolhem F.; Poizot P. A Dual-Ion Battery using Diamino-Rubicene as Anion-Inserting Positive Electrode Material. Electrochem. Commun. 2016, 72, 64-68.

(28) Fan L.; Liu Q.; Xu Z.; Lu B. An Organic Cathode for Potassium Dual-Ion Full Battery. ACS Energy Lett. 2017, 2, 1614-1620. 